\title{
ЗЕМЕЛЬНА ДІЛЯНКА ЯК ОСОБЛИВИЙ I САМОСТІЙНИЙ ОБ’ЄКТ ЗЕМЕЛЬНИХ ПРАВОВІДНОСИН
}

\begin{abstract}
Анотація. У статті автор розмежовує поняття «земля» та «земельна ділянка», обгрунтовує визначення земельної ділянки та категорії майна, вказує на доцільність ширшого розуміння функцій земельної ділянки, таких як адміністративна, культурна, історична, економічна, екологічна. Автор вносить нове розуміння земельної ділянки як динамічної субстанції, яка змінюється у процесі її використання. Зазначає, що формування земельної ділянки має технічну та юридичну сторони. До технічної сторони належить процес рекультивації: навезення відповідного грунту, планування; біологічний етап - коли земельна ділянка зазнає насичення добривами тощо. Лише після цього можна говорити, що земельна ділянка сформована. У процесі використання земельна ділянка зазнає змін відповідно до потреб користувача, власника. У статті автор доходить висновку, що формування вектора розвитку земельних відносин на державному рівні має відбуватися у контексті сприйняття земельної ділянки як особливої, поліфункціональної, динамічної категорії.
\end{abstract}

Ключові слова: земля, земельна ділянка, перехід прав на земельні ділянки, об'єкт земельних правовідносин.

Постановка проблеми. У процесі реформування земельних відносин важливим є розуміння природи та цінності земельної ділянки як частинки такого ресурсу, як земля; ïх місця у житті людини та ролі для людства у сучасності та в майбутньому. Наявне сприйняття у законодавстві земельної ділянки як майна звужує роль цього ресурсу. Такий підхід не стимулює землекористувачів та землевласників до підвищення якості земельної ділянки, іiі перспективного використання, а лише спрямовує на досягнення економічної ефективності користування. Такі наукові напрацювання можуть бути використанні в процесі кодифікації правових форм переходу права власності на земельні ділянки.

Завданням цієї статті є розширення розуміння земельної ділянки як динамічної субстанції, яка трансформується у процесі іiі використання відповідно до потреб та розуміння ïi власника (користувача) та необхідності відображення природи земельної ділянки у законодавстві задля забезпечення конституційної норми, яка передбачає, що земля є основним національним багатством.

Метою статті є формулювання юридичних та ціннісних підходів у розумінні земельної ділянки як об' єкта земельних правовідносин.

Виклад основного матеріалу дослідження. У правовій літературі існує дискусія стосовно визначення земельної ділянки як речі, майна. Стаття 181 ЦК України прямо відносить земельні ділянки до нерухомих речей, а отже, до майна. 3 етимологічної точки зору слово «майно» походить від дієслова «мати» (володіти). Тобто майно - це те, що можна мати, чим можна володіти. Безумовно, володіти можна і земельною ділянкою.
Дослідженню земельної ділянки як об'єкта права власності приділив увагу професор I.I. Каракаш. Так, автор зазначає, що земля як об'єкт права власності може розглядатися у різних аспектах, зокрема як об'єкт землеустрою, об'єкт охорони і захисту прав землевласників, об'єкт відшкодування заподіяних збитків власникам [10].

На думку О.Г. Бондаря, який спеціально досліджував землю як об'єкт права власності, «земельна нерухомість не має принципово важливих особливостей, що дає змогу відокремити іiі від речей, і може розглядатися як різновид нерухомого майна». Він доходить висновків про більшу прийнятність вживання терміна «земельна нерухомість» [1].

Позицію віднесення землі до об'єктів нерухомого майна висловив проф. В.В. Носік, який вказує, що земля є нерухомістю внаслідок об' єктивних факторів, незалежно від розміщення на ній іншого майна [9].

На думку авторів Науково-практичного коментаря Земельного кодексу України А.М. Мірошніченка, Р.К. Марусенка, земельна ділянка - це специфічний різновид майна. Такий підхід сформульовано авторами, спираючись на етимологію слова «майно», що походить від дієслова «мати», «володіти». Автори зазначають, що майно - це те, що можна мати, чим можна володіти [4].

На противагу висловленим думкам учених академік B.I. Андрейцев вважає, що земля та земельні ділянки невиправдано віднесено до майнових, речових об'єктів та, відповідно, до речового права. За такого підходу не взято до уваги ту важливу обставину, що з точки зору предметів та явищ, які оточують людину, такі блага за своїм походженням можуть бути віднесені до матеріальних або духовних благ. Земля, як зазначає автор, безумовно, є матеріальним об'єктом природного походження, яка з точки зору еколого-економічної оцінки належить до природних ресурсів, а не до категорії речей як об'єктів матеріального виробництва, які виступають водночас об' Єктами цивільних правовідносин, зокрема речового обміну і відповідного правового регулювання [3].

H.I. Титова доводить, що під визначення речі (майно) не може підпадати земля у розумінні частки навколишнього середовища, оскільки вона, не будучи індивідуалізованою, не може бути об'єктом цивільних прав та обов'язків. Вчена зазначає, що нерухомість майна в цивілістичному аспекті $€$ відносною, а нерухомість землі абсолютною, землі існують об'єктивно, незалежно від впливу людини на противагу майну, виникнення та існування якого залежить від людини [2].

Земельний кодекс України визначає об'єкти правовідносин, під якими згідно з частиною 3 статті 2 розуміються землі у межах території України, земельні ділянки та права на них, зокрема на земельні частки (паі).

Земельний кодекс України дає визначення земельної ділянки, але це визначення стосується тих земельних ділянок, які 
набуваються, коли земельна ділянка як така, із відповідним складом різноманітних гуртів та відповідними межами переходить до громадян, але земельна ділянка (iї ландшафт, склад, насадження, будівлі на ній) формується у процесі використання. Має місце перманентний процес формування земельної ділянки. Це не управлінські дії з оформлення земельної ділянки, з відповідним кадастровим номером, а формування структури земельної ділянки. Формування земельної ділянки має технічну та юридичну сторони. До технічної сторони належить процес рекультивації: навезення відповідного грунту, планування; біологічний етап - коли земельна ділянка зазнає насичення добривами тощо. Лише після цього можна говорити, що земельна ділянка сформована. Сформована у структурному плані: зонування. У процесі використання земельна ділянка зазнає змін відповідно до потреб користувача, власника. Це включається до категорії формування земельної ділянки та впливу людини на цей процес. Економічна оцінка залежить від проходження такого процесу формування. Ми доходимо до того, що земельна ділянка набуває характеристики земельного ландшафту. Земельна ділянка залишається як матеріальна основа, але змінюється 3 точки зору характеру, оскільки змінюються функції, які вона набуває в процесі використання. Цей процес є свідомим та цілеспрямованим. Таким чином, крім конфігурації, у земельній ділянці все може змінюватись і навіть цільове призначення. Таким чином, має місце трансформація у природі земельної ділянки як об'єкта права, трансформація відповідно до вимог та потреб власника та у межах приписів земельного законодавства.

У процесі використання земельна ділянка може змінювати свій правовий режим. Характеристика земельної ділянки змінюється, вона набуває нових якостей та споживчих властивостей задля задоволення інтересів власника. Таким чином, така земельна ділянка 3 точки зору економічної оцінки може перевищувати свою первісну вартість.

Вважаємо, що це має бути новий підхід у земельному праві та законодавстві. Водночас земельний кодекс не реагує на такі зміни. Отже, постає запитання: як оцінити культурне, рекреаційне, оздоровче призначення земельної ділянки? Така земельна ділянка як об'єкт має вже соціальне значення. Чинний Земельний кодекс України не враховує усього матеріального, що на земельній ділянці $€$.

У такому аспекті ми говоримо про земельну ділянку як матеріальну основу територіального простору та певного ландшафту. Тому земельна ділянка перетворюється на біологічний комплекс, який сприяє якості життя та безпеки людини.

Земельна ділянка не є статичною категорією, вона постійно змінюється залежно від потреб, творчості, життєдіяльності власника та перетворюється на новий об'єкт з точки зору виконуваних земельною ділянкою функцій.

За такого підходу земельна ділянка з об'єкта земельного права стає об'єктом екологічного права.

В юридичній літературі існує неоднозначний підхід до визначення об'єктів земельних правовідносин.

Академік B.I. Андрейцев вважає, що у реальних земельних правовідносинах виступають землі як конкретні категорії земель України, перелік яких ЗК України визнав вичерпним без достатніх формально-юридичних та реальних умов використання, відтворення та охорони, обмеживши їх земельно-правовий режим та належність реальним суб'єктам. Категорія «земля» - законодавчо легалізоване узагальнене поняття. Про диференційовані об'єкти земельних правовідносин правильно говорити «землі України», тобто такі, які становлять національне багатство, що характеризує матеріальну основу формування та функціонування української нації і суспільства, здійснення суверенних прав українського народу, функціонування держави, їі територіальної цілісності, суверенітету, національної безпеки, встановлення та реалізації адміністративно-територіального поділу країни [5].

Конституційне закріплення правової категорії «основне національне багатство» зумовлює визнання землі як особливого об' єкта правового регулювання, встановлення специфічного правового режиму з урахуванням ії поліфункціонального призначення в життєдіяльності нації та формування і розвитку українського суспільства, індивідуалізації та виокремлення із системи інших об'єктів національного багатства, інтеграції та диференціації відповідних земельних правовідносин та їх правового опосередкування на рівні самостійного законодавчого акта, в цьому разі ЗК України [6].

Отже, земля, на думку академіка В.I. Андрейцева, може розглядатися як інтегрований та диференційований об'єкт, що зумовлює доцільність подальшої правової регламентації.

Російський учений Ю.Г. Жариков відносить до об'єктів земельного права індивідуально визначену земельну ділянку, щодо якої виникають земельні відносини. У сфері державного управління об'єктом земельних відносин може бути увесь земельний фонд у цілому, його складники у межах кордонів суб'єктів держави, адміністративно-територіальних громад, окремі ділянки [7].

Українські правознавці О.О. Погрібний та О.М. Пащенко вважають, що об'єктами земельних правовідносин є землі в межах території України, індивідуально визначені земельні ділянки, земельні частки (паї) та права на них.

Професор Н.I. Титова звертала увагу на те, що термін «землі» правильно вживається у земельному законодавстві як елемент природного середовища, що перебуває в органічному взаємозв'язку з іншими його елементами (вода, ліси, атмосферне повітря тощо), на відміну від терміна «земля» [8].

На наш погляд, земля не виступає об'єктом переходу права власності громадян, а лише земельні ділянки, на які спрямовується інтерес фізичної та юридичної особи та стосовно яких встановлюється їх земельна правосуб'єктність і оформляється відповідний юридичний титул - право власності чи право користування.

Підтвердженням цього є норми ЗК України, які у визначенні правових форм переходу права власності використовують категорію «земельні ділянки»: стаття 118 «Порядок безоплатної приватизації земельних ділянок громадянами»; стаття 119 «Набуття права на земельну ділянку за давністю користування (набувальна давність)»; стаття 120 «Перехід права власності на земельну ділянку при переході права на житловий будинок, будівлю або споруду»; стаття 127 «Продаж земельних ділянок державної чи комунальної власності або прав на них»; стаття 127 «Продаж земельних ділянок державної чи комунальної власності або прав на них»; стаття 131 «Набуття права власності на земельні ділянки на підставі інших цивільно-правових угод»; статті 134 «Обов’язковість продажу земельних ділянок державної чи комунальної власності або прав на них на конкурентних засадах» (земельних торгах); стаття 140 «Підстави припинення 
права власності на земельну ділянку»; стаття 142 «Добровільна відмова від права власності або права постійного користування земельною ділянкою»; стаття 146 «Викуп земельних ділянок для суспільних потреб»; стаття 148 «Конфіскація земельної ділянки»; стаття 149 «Порядок вилучення земельних ділянок».

Формування вектора розвитку земельних відносин на державному рівні має відбуватися у контексті сприйняття земельної ділянки як особливої, поліфункціональної категорії. Земельна ділянка виконує важливі культурну, історичну, економічну, екологічну функції, є динамічною у процесі іiї використання та перебуває у перманентному процесі правової трансформації.

Висновки. На підставі викладеного можна зробити такі висновки.

По-перше, земельна ділянка - це територіально та юридично визначений природний простір із зазначеною межею використання, відтворення та охорони титулованого власника на неї щодо визначення іiї цільової експлуатації та переходу прав до іншого суб'єкта власності.

По-друге, правовий режим земельної ділянки визначається земельно-правовою документацією, цільовим використанням та можливістю власника щодо поліпшення структури, розташування на ній об' єктів майново-господарського призначення 3 метою задоволення його інтересів та відповідно до кадастрового використання у структурі земель відповідної категорії.

По-третє, цільове використання земельної ділянки мусить мати мобільний характер відповідно до потреб та інтересів власника 3 можливістю зміни характеру іiї використання та юридичного оформлення кадастрової документації.

По-четверте, земельна ділянка - це різновид природного ресурсу, що належить фізичній або юридичній особі на відповідному юридичному титулі з можливістю переходу до іншого суб' єкта відповідно до процедур, регламентованих Земельним кодексом України та прийнятих на його розвиток інших актів законодавства.

По-п'яте, держава (відповідно до Конституції України) зобов'язалася гарантувати власнику земельної ділянки захист його прав у встановленому законодавством порядку щодо відчуження земельної ділянки та переходу прав на неї іншому власнику, якщо інше не встановлене Земельним кодексом України.

\section{Лimepamypa:}

1. Бондар О.Г. Земля як об'єкт права власності за земельним законодавством України: автореф. дис. ... канд. юрид. наук: за спеціальністю 12.00.06. Київ, 2005. 22 с.

2. Земельне право України / М.В. Шульга, Г.В. Анасімова, Н.О. Бажай, А.П. Гетьман. Київ, 2004. 368 с

3. Організаційно-правові проблеми розвитку аграрного та земельного ринків в Україні: тези доповідей і наукових повідомлень на науково-практичній конференції (8 липня 2003 р.). Київ, 2004. 129 с.

4. Земельний кодекс України: наук.-практ. коментар / А.М. Мірошниченко, Р.І. Марусенко. Київ, 2016. 496 с.

5. Андрейцев В.І. Земельне право і законодавство суверенної України: актуальні проблеми практичної теорії. Київ. 2007. 445 с.

6. Андрейцев B.I. Суверенній Україні - нову земельну Конституцію (концептуальні підходи до підготовки проекту Кодексу законів про землю). Право України. 1999. № 8. С. 58-65.
7. Земельне право / за ред. В.І. Семчика, П.Ф. Кулинича. Київ. 2001. $424 \mathrm{c}$.

8. Титова Н. Землі як об’єкт правового регулювання. Право України. 1998. № 4. C. 12.

9. Право власності в Україні: навч. посібник. / за заг. ред. О.В. Дзери, Н.С. Кузнєцової. Київ. 2000. 816 с.

10. Каракаш I.І. Право власності на природні об’єкти та їх ресурси в Україні. Одеса. 2017. 436 с.

Щербяк Ю. В. Земельный участок как особый и самостоятельный объект земельных правоотношений

Аннотация. В статье автор исследует разграничение понятий «земля» и «земельный участок», обоснованность отнесения в законодательстве Украины «земельного участка» к категории имущества. Указывает на целесообразность широкого восприятия функций земельного участка, таких как административная, культурная, историческая, економическая, екологическая, другие. Автор вносит новое понимание «земельного участка» как динамической субстанции, которая меняется в процесе ее использования. Отмечает, что формирование земельного участка имеет техническую и юридическую стороны. К технической стороне можна отнести процес рекультивации: навезение соответствующей почвы, планирование; биологический етап - когда земельный участок насыщается минеральными удобрениями.

Только после этого можна говорить, що земельный участок сформирован. В процесе использования земельный участок меняется в соответстии с требованиями пользователя, собственника. В статье автор приходит к выводу, что формирование вектора развития земельных отношений на государственном уровне должно происходить через призму восприятия земельного участка как особой, полифункциональной, динамической субстанции.

Ключевые слова: земля, земельный участок, переход прав на земельный участок, объект земельных правоотношений.

Sherbyak J. Land as a special object of land relations

Summary. In the article, the author explores the distinction between the concepts of "land" and "land plot", the validity of attributing in the legislation of Ukraine "land" to the category of property. Indicates the feasibility of a broad perception of the functions of the land such as administrative, cultural, historical, economic, ecological, and others. The author introduces a new understanding of the "land plot" as a dynamic substance that changes during its use. Notes that the formation of the land has a technical and legal aspects. The technical side can be attributed reclamation process: the introduction of appropriate soil planning; biological step - when the land is saturated with mineral fertilizers.

Only after that we can say that the land plot is formed. In the process of using the land plot changes accordingly to the requirements of the user, the owner. In the article the author comes to the conclusion that the formation of the vector of development of land relations at the state level should occur through the prism of the perception of the land as a special, polyfunctional, dynamic substance.

Key words: land, land plot, transfer of land rights, object of land legal relations. 